\title{
PENGARUH NITRIDASI ION SUHU RENDAH PADA KETAHANAN AUS DAN KOROSI BIOMATERIAL STAINLESS STEEL AUSTENITIK 316L
}

\author{
Sudjatmoko, Bambang Siswanto, Wirjoadi, Lely Susita RM \\ Pusat Teknologi Akselerator dan Proses Bahan, BATAN \\ Jl. Babarsari Kotak Pos 6101 Ykbb, Yogyakarta 55281 \\ e-mail: sd_moko@yahoo.co.id
}

Diterima 03 Juli 2012, diterima dalam bentuk perbaikan 27 Juli 2012, disetujui 30 Juli 2012

\begin{abstract}
ABSTRAK
PENGARUH NITRIDASI ION SUHU RENDAH PADA KETAHANAN AUS DAN KOROSI BIOMATERIAL STAINLESS STEEL AUSTENITIK 316L. Dalam penelitian ini telah selesai dilakukan proses nitridasi ion dan karakterisasi cuplikan SS 316L. Proses nitridasi ion telah dilakukan pada cuplikan untuk variasi suhu nitridasi 350, 400, 450, 500, dan $550^{\circ} \mathrm{C}$, pada tekanan gas nitrogen optimum 1,8 mbar dan waktu nitridasi optimum 3 jam. Struktur-mikro, komposisi unsur dan struktur fase lapisan nitrida yang terbentuk pada permukaan cuplikan diamati menggunakan teknik SEM-EDAX dan XRD, dan diketahui bahwa lapisan tipis nitrida besi telah terbentuk pada permukaan cuplikan. Lapisan nitrida besi tersebut mempunyai struktur fase antara lain $\varepsilon-\mathrm{Fe}_{2-3} \mathrm{~N}, \gamma^{\prime}-\mathrm{Fe} \mathrm{A}_{4} \mathrm{~N}, \mathrm{CrN}, \mathrm{Cr}_{2} \mathrm{~N}$ dan austenit terekspansi zw yang mempunyai sifat-sifat istimewa. Hasil karakterisasi ketahanan aus cuplikan SS 316L menunjukkan terjadinya peningkatan ketahanan aus sekitar 2,6 kali cuplikan standar pada suhu nitridasi $350{ }^{\circ} \mathrm{C}$, dan dari uji korosi dengan larutan Hanks diperoleh laju korosi optimum 29,87 mpy atau ketahanan korosinya meningkat sekitar 137\%. Dengan demikian dapat diketahui bahwa dengan menggunakan teknik nitridasi ion telah terbentuk lapisan nitrida besi pada permukaan cuplikan SS 316L, dan mereka mempunyai sifat ketahanan aus dan ketahanan korosi sangat baik. Sifat kekerasan yang tinggi dan mempunyai ketahanan korosi yang baik tersebut, terutama disebabkan terbentuknya nitrida besi dan fase austenit terekspansi zw pada proses nitridasi suhu rendah.
\end{abstract}

Kata kunci: Nitridasi ion, ketahanan aus, ketahanan korosi, fase austenit terekspansi

\section{ABSTRACT}

EFFECT OF THE LOW TEMPERATURE ION NITRIDING ON THE WEAR AND CORROSION RESISTANCE OF 316L AUSTENITIC STAINLESS STEEL BIOMATERIALS. In the present study has been completed done the ion nitriding process and characterization of the $316 \mathrm{~L}$ SS samples. The ion nitriding process has been conducted on the samples for nitriding temperature variation of $350,400,450,500$, and $550^{\circ} \mathrm{C}$, the optimum nitrogen gas pressure of 1.8 mbar and optimum nitriding time of 3 hours. The micro-structure, elemental composition and the phase structure of the nitride layer formed on the surface of samples were observed using the techniques of SEM-EDAX and XRD, respectively. It is known that a thin layer of iron nitrides has been formed on the surface of the samples. Iron nitride layer has a phase structure including $\varepsilon-\mathrm{Fe}_{2-3} \mathrm{~N}, \gamma-\mathrm{Fe}_{4} \mathrm{~N}, \mathrm{CrN}, \mathrm{Cr}_{2} \mathrm{~N}$ and expanded austenite $2 \mathrm{~N}$. The characterization results of the wear resistance of the 316L SS samples showed an increasing of about 2.6 times the wear resistance of standard samples after nitriding temperature of $350{ }^{\circ} \mathrm{C}$. From the corrosion test by using the Hanks solution was obtained 29.87 mpy corrosion rate or the increasing of corrosion resistance of about $137 \%$. Thus it can be seen that by using ion nitriding technique the iron nitride layer has been formed on the surface of the 316L SS samples, and they have an excellent properties of wear resistance and corrosion resistance, which were caused especially due to the formation of an expanded austenite $\mathrm{j}$. Properties of the high hardness and has the good corrosion resistance, especially due to the formation of iron nitride and expanded austenite phases $\mathrm{w}$ at low temperature nitriding process.

Keywords: Ion nitriding, wear resistance, corrosion resistance, phase of expanded austenite

\section{PENDAHULUAN}

Denggunaan material lapisan tipis dan komponen permukaan yang direkayasa semakin meningkat dan didorong oleh kebutuhan untuk memperbaiki dan meningkatkan nilai kekerasan, ketahanan korosi dan ketahanan aus suatu permukaan material. Stainless steel austenitik adalah kelompok stainless steel yang paling penting berkaitan dengan pemanfaatannya yang sangat luas dalam berbagai bidang industri, dan juga sebagai biomaterial yang dimanfaatkan dalam bidang kedokteran. Stainless steel mempunyai sifat ketahanan korosi yang sangat baik disebabkan karena pembentukan selaput permukaan pasif (a passive surface film), akan tetapi untuk berbagai 
Pengaruh Nitridasi lon Suhu Rendah Pada Ketahanan Aus dan Korosi Biomaterial Stainless Steel Austenitik $316 \mathrm{~L}$ (Sudjatmoko, Bambag Siswanto, Wirjoadi, Lely Susita RM.)

macam aplikasi industri kekerasan permukaannya relatif rendah dan ketahanan ausnya kurang memadai (1-6). Ketahanan aus komponen stainless steel pada umumnya dapat ditingkatkan dengan teknik rekayasa permukaan (surface engineering techniques), yaitu memodifikasi sifat-sifat lapisan permukaan dengan cara proses pelapisan (coating processes) seperti deposisi uap secara fisika (physical vapor deposition), deposisi uap secara kimia (chemical vapor deposition) atau semprotan plasma (plasma spray), PI3 (plasma immersion ion implantation), teknik implantasi ion maupun proses difusi seperti karburasi atau nitridasi ion $(4,7,8,9)$. Beberapa penelitian yang dilakukan telah menunjukkan bahwa nitridasi ion terhadap stainless steel pada suhu relatif rendah menghasilkan lapisan permukaan keras yang menghasilkan terjadinya peningkatan ketahanan aus tanpa mengurangi ketahanan korosi $(2,3,7,10)$.

Nitridasi ion atau juga disebut nitridasi plasma adalah suatu proses termokimia (thermochemical process) untuk memperbaiki sifat-sifat permukaan material, seperti pengerasan permukaan, ketahanan aus, ketahanan korosi dan kekuatan lelah (fatigue strength) dari berbagai macam stainless steel (11-14). Pada saat ini nitridasi ion telah banyak digunakan dalam kegiatan industri untuk meningkatkan ketahanan aus dan ketahanan korosi komponen-komponen berbasis stainless steel. Nitridasi ion adalah proses di mana nitrogen dimasukkan ke permukaan stainless steel pada suhu tertentu. Nitridasi ion ini adalah metode pengerasan permukaan memanfaatkan teknologi lucutan pijar (glow discharge technology) untuk memasukkan unsur nitrogen ke permukaan diikuti dengan proses difusi ke dalam material $(1,8)$. Proses ini dilakukan dalam ruang hampa di bawah tegangan tinggi dan ion-ion dalam plasma yang terbentuk dipercepat menumbuk permukaan benda kerja. Proses tumbukan ion tersebut memanaskan benda kerja dan membersihkan permukaan, sehingga menyebabkan nitrogen aktif dalam pengaruh lucutan pijar untuk membentuk lapisan tipis nitrida besi.

Pada umumnya nitridasi ion konvensional dilakukan pada suhu nitridasi di atas $500{ }^{\circ} \mathrm{C}$ agar dihasilkan lapisan ternitridasi yang tebal pada permukaan cuplikan, yang secara signifikan meningkatkan kekerasan permukaan dan sifat keausan ${ }^{(10,17)}$. Akan tetapi ketahanan korosi dari permukaan stainless steel austenitik berkurang secara dramatis akibat pembentukan nitrida krom $(\mathrm{CrN})$ selama perlakuan permukaan, karena terjadinya penurunan kandungan krom bebas yang tersedia dalam matriks stainless steel untuk pembentukan lapisan permukaan protektif (the protective surface film) (2,10,15). Untuk menghindari terjadinya pengendapan $\mathrm{CrN}$, nitridasi ion dapat dilakukan pada suhu rendah, biasanya di bawah suhu $450^{\circ} \mathrm{C}$, dan dihasilkan fase austenit terekspansi (expanded austenite) $\gamma_{\mathrm{N}}$ atau fase-S yang mempunyai kekerasan tinggi dan ketahanan korosi yang lebih baik. Suhu nitridasi yang rendah dan distorsi perlakuan panas yang rendah (low heat treatment distortion) dari proses nitridasi ion telah menarik minat yang besar dari sudut pandang teknologi, dan banyak penelitian telah dilakukan untuk mendapatkan kekerasan permukaan yang tinggi tanpa terjadi degradasi ketahanan korosi.

Dalam penelitian ini dilakukan kajian pengaruh suhu nitridasi rendah terhadap peningkatan ketahanan aus dan korosi stainless steel AISI 316L, pembentukan fase austenit terekspansi, juga pengaruhnya terhadap struktur-mikro dan struktur fase dari permukaan cuplikan yang ternitridasi. Uji ketahanan aus dilakukan menggunakan alat uji keausan berdasarkan pada laju material yang terauskan atau jumlah material yang aus per satuan jarak luncur atau waktu pengausan; sedangkan ketahanan korosi diukur dengan alat uji korosi potensiostat PGS-201T menggunakan larutan Hanks, yaitu larutan yang disimulasikan seperti cairan dalam tubuh manusia. Analisis struktur-mikro dilakukan menggunakan teknik SEM (Scanning Electron Microscopy) dan analisis struktur fase kristalin dilakukan menggunakan teknik difraksi sinar-X (XRD).

\section{METODOLOGI}

\section{Bahan}

Bahan yang digunakan dalam proses nitridasi ion adalah biomaterial berbasis besi berupa stainless steel austenitik jenis 316L dengan kemurnian (\% berat): $\mathrm{Fe}-69 \%$, Cr-18\%, Ni-10\%, Mo-3\%; gas nitrogen, dan bahan-bahan yang digunakan dalam pembuatan larutan Hanks untuk uji korosi terdiri dari $\mathrm{NaCl}, \mathrm{CaCl}_{2}, \mathrm{KCl}$, $\mathrm{NaHCO}_{3}$, glukosa, $\mathrm{NaH}_{2} \mathrm{PO}_{4}, \mathrm{MgCl}_{2} .6 \mathrm{H}_{2} \mathrm{O}, \mathrm{Na}_{2} \mathrm{HPO}_{4} .2 \mathrm{H}_{2} \mathrm{O}$, dan $\mathrm{MgSO}_{4} .7 \mathrm{H}_{2} \mathrm{O}$ produksi PT Merck yang memiliki tingkat kemurnian $99,5 \%$.

\section{Alat}

Peralatan yang digunakan dalam penelitian ini terdiri dari: peralatan nitridasi ion yang dilengkapi dengan sumber tegangan tinggi dc, sistem vakum, sistem masukan gas dan regulator suhu; alat uji keausan, alat uji korosi 
potensiostat PGS-201T, SEM-EDAX merk Jeol JSM-636 OLA, dan difraktometer sinar-X (XRD) tipe Simadzu XRD-6000 menggunakan sumber radiasi CuK $\alpha$ dengan panjang gelombang $1,54056 \AA$.

\section{Tata Kerja}

Bahan yang digunakan untuk cuplikan berupa stainless steel austenitik jenis $316 \mathrm{~L}$ ukuran $1,0 \mathrm{~cm} \times 1,0 \mathrm{~cm}$ dan tebal 2,0 mm dibuat menurut teknik metalografi konvensional dengan pengampelasan dan penghalusan permukaan. Pengampelasan dilakukan menggunakan kertas ampelas, selanjutnya dipoles atau dihaluskan menggunakan pasta intan dan digosok dengan kain beludru sampai dihasilkan permukaan yang halus dan mengkilap. Untuk menghilangkan kotoran pada permukaan cuplikan dilakukan pencucian menggunakan alkohol dan kemudian dimasukkan ke dalam pembersih ultrasonik.

Setelah diperoleh cuplikan dilanjutkan dengan proses nitridasi ion yang dilakukan menggunakan peralatan nitridasi ion. Peralatan tersebut terdiri dari bejana vakum terbuat dari logam dilengkapi dengan sistem vakum, sistem masukan gas nitrogen, sistem tegangan tinggi dc $300-1.200$ volt dan regulator suhu. Pada penelitian ini suhu nitridasi ion divariasi pada kisaran $350,400,450,500$ dan $550^{\circ} \mathrm{C}$; sedangkan tekanan gas nitrogen divariasi untuk nilai 1,2; 1,4;1,6; 1,8; 2,0 dan 2,4 mbar; dan variasi waktu nitridasi ion 1, 2, 3, 4 dan 5 jam.

Ketahanan aus cuplikan ditentukan berdasarkan pada laju material yang terauskan atau jumlah material yang aus (massa, volume atau tebal) per satuan jarak luncur atau waktu pengausan, dimana beban pengaus adalah 319,376 gram dan waktu pengausan selama 15 menit. Ketahanan korosi cuplikan ditentukan menggunakan alat uji korosi potensiostat PGS-201T untuk mengukur besarnya arus korosi $I_{\text {kor. }}$. Besarnya laju korosi sebagai fungsi dari arus korosi (ampere $/ \mathrm{m}^{2}$ ), yaitu besarnya arus listrik yang mengalir dari anode menuju ke katode atau sebaliknya, rapat jenis bahan dan luas cuplikan. Untuk mengetahui struktur mikro dan komposisi unsur permukaan cuplikan dilakukan analisis dengan menggunakan SEM (Scanning Electron Microscope) dan EDAX (Energy Dispersive Analysis X-Ray); sedangkan untuk mengetahui struktur fase kristalin dari lapisan tipis nitrida dilakukan pengujian dengan XRD (X-ray Diffraction) menggunakan metode pencocokan dengan data JCPDS.

\section{HASIL DAN PEMBAHASAN}

Mikrograf SEM dari tampang-lintang cuplikan SS $316 \mathrm{~L}$ setelah dinitridasi ion pada suhu $350^{\circ} \mathrm{C}$, tekanan gas nitrogen dan waktu nitridasi optimum masing-masing pada 1,8 mbar dan 3 jam ditampilkan pada Gambar 1. Berdasarkan mekanisme nitridasi ion untuk cuplikan berbasis $\mathrm{Fe}$, atom-atom besi yang terpercik keluar dari permukaan cuplikan akibat tumbukan ion-ion nitrogen bereaksi dengan nitrogen dalam fase gas untuk membentuk FeN yang tidak stabil, selanjutnya terkondensasi pada permukaan cuplikan, melepaskan nitrogen dan membentuk nitrida besi yang lebih stabil seperti struktur fase $\varepsilon-\mathrm{Fe}_{2-3} \mathrm{~N}$ dan $\gamma^{\prime}-\mathrm{Fe}_{4} \mathrm{~N}$. Dalam proses nitridasi ion tersebut terbentuk dua jenis lapisan nitrida, yaitu lapisan senyawa (compound layer) yang berwarna putih yang mempunyai struktur fase $\gamma^{\prime}-\mathrm{Fe}_{4} \mathrm{~N}$ atau fase $\varepsilon-\mathrm{Fe}_{2-3} \mathrm{~N}$, dan daerah difusi (diffusion zone) di bawah lapisan senyawa (14,16), seperti ditunjukkan pada Gambar 1. Lapisan senyawa tersebut mempunyai sifat sangat keras sehingga tahan terhadap keausan.

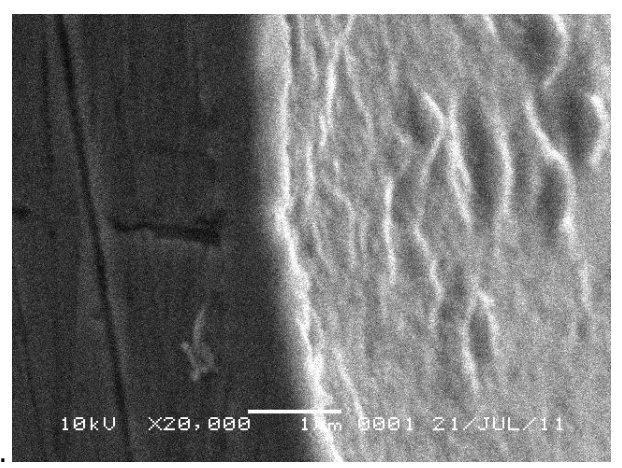

Gambar 1. Mikrograf SEM dari tampang-lintang cuplikan SS $316 \mathrm{~L}$ setelah dinitridasi ion pada suhu $350^{\circ} \mathrm{C}$, tekanan gas nitrogen optimum 1,8 mbar dan waktu nitridasi optimum 3 jam.

Dalam penelitian ini juga dilakukan pengamatan struktur-mikro dan komposisi unsur menggunakan teknik SEM-EDAX, terutama untuk mengetahui kandungan unsur nitrogen pada permukaan cuplikan setelah proses 
Pengaruh Nitridasi lon Suhu Rendah Pada Ketahanan Aus dan Korosi Biomaterial Stainless Steel Austenitik $316 \mathrm{~L}$ (Sudjatmoko, Bambag Siswanto, Wirjoadi, Lely Susita RM.)

nitridasi ion. Pada Gambar 2 ditampilkan mikrograf SEM-EDAX cuplikan SS 316L hasil nitridasi ion untuk variasi suhu nitridasi 350,500 dan $550^{\circ} \mathrm{C}$ pada tekanan gas nitrogen dan waktu nitridasi optimum masing-masing adalah 1,8 mbar dan 3 jam. Berdasarkan Gambar 2 tersebut dapat diketahui bahwa besarnya kandungan nitrogen yang terdepositkan pada permukaan cuplikan SS 316L dipengaruhi oleh suhu nitridasi ion. Pada suhu nitridasi yang semakin tinggi persentase atom nitrogen semakin naik, persentase atom krom relatif tetap dan persentase atom besi semakin menurun. Pada suhu nitridasi di bawah $400^{\circ} \mathrm{C}$ akan terbentuk fase austenit terekspansi $\gamma_{\mathrm{N}}$, dan pada suhu yang lebih tinggi akan terbentuk fase $\gamma^{\prime}-\mathrm{Fe}_{4} \mathrm{~N}, \varepsilon-\mathrm{Fe}_{2-3} \mathrm{~N}$ dan $\mathrm{CrN}{ }^{(1,7,9)}$, sedangkan pada suhu di atas $500{ }^{\circ} \mathrm{C}$ terjadi presipitasi nitrida krom yang mengakibatkan terjadinya degradasi ketahanan korosi SS 316L (4,9,14,16). Untuk menentukan struktur fase nitrida yang terbentuk pada permukaan cuplikan SS 316L tersebut digunakan teknik XRD.

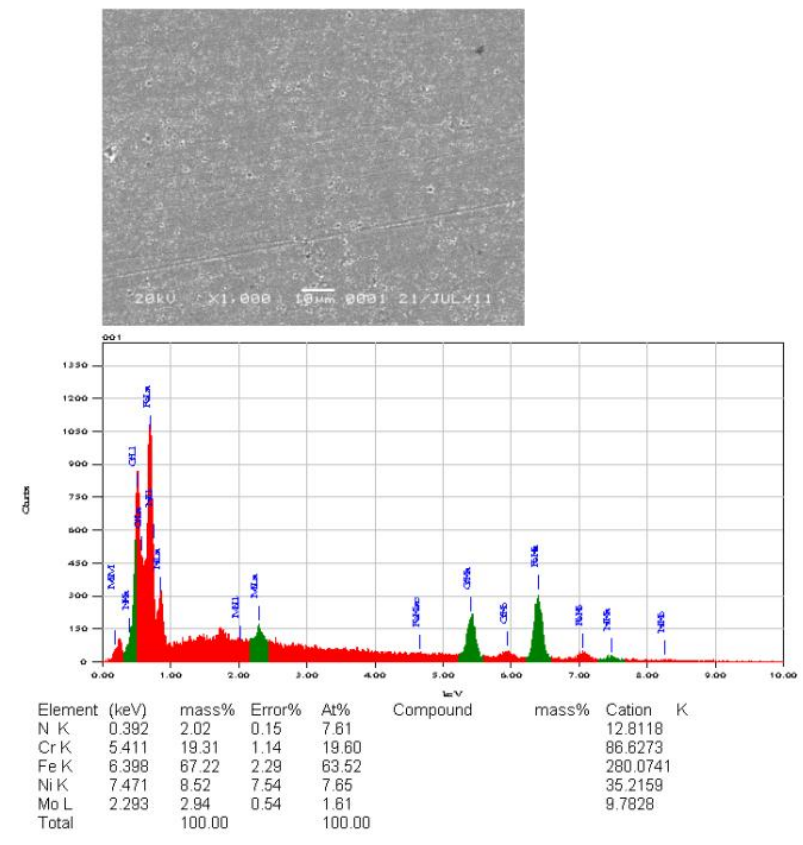

(a)

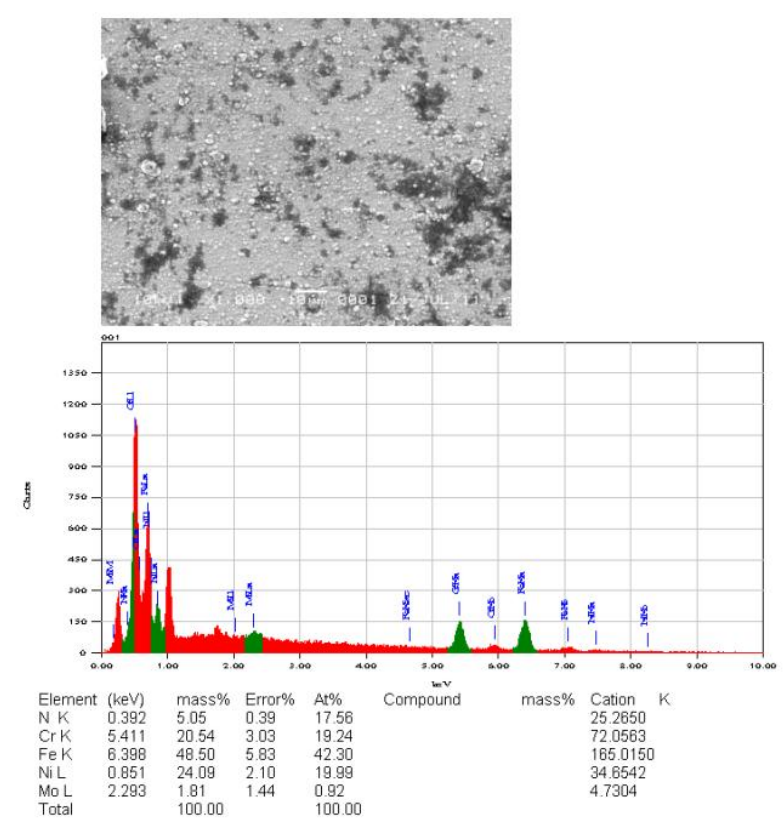

(b) 


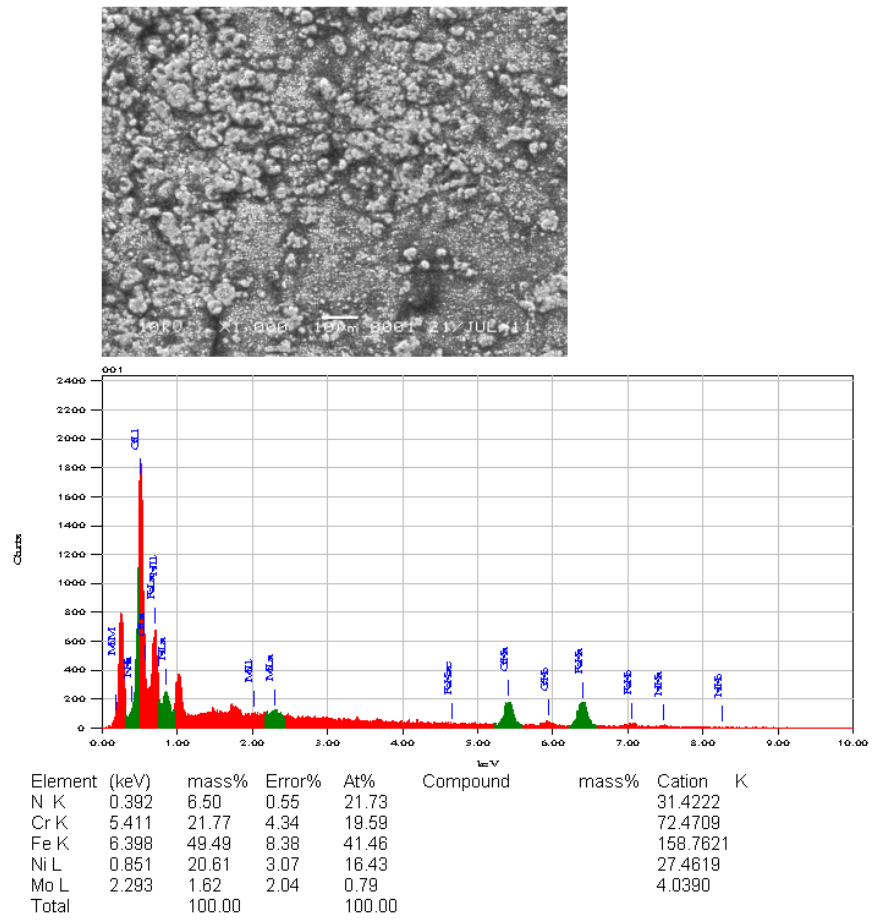

(c)

Gambar 2. Mikrograf SEM-EDAX cuplikan SS 316L hasil nitridasi ion untuk variasi suhu nitridasi, pada tekanan gas nitrogen optimum 1,8 mbar dan waktu nitridasi optimum 3 jam, (a) suhu $350^{\circ} \mathrm{C}$, (b) suhu $500{ }^{\circ} \mathrm{C}$ dan (c) suhu $550{ }^{\circ} \mathrm{C}$.

Keausan merupakan peristiwa gesekan dan pelepasan partikel-partikel metal dari permukaannya yang disebabkan oleh metal atau logam lainnya, bahan non metal, cairan atau gas yang bergerak. Dalam penelitian ini ketahanan aus ditentukan menggunakan alat uji aus yang berdasarkan pada jumlah material cuplikan yang terauskan, yaitu massa per satuan waktu pengausan. Berat beban pengaus adalah 319,376 gram dan waktu pengausan selama 15 menit. Berdasarkan Gambar 3 dapat diketahui bahwa cuplikan SS 316 mengalami pengurangan berat optimum sebesar $0,2 \mathrm{mg}$ atau terjadi peningkatan ketahanan aus optimum sekitar 14,5 kali dibandingkan dengan cuplikan standar, pada suhu nitridasi optimum $450^{\circ} \mathrm{C}$, dan tekanan gas nitrogen dan waktu nitridasi optimum masing-masing 1,8 mbar dan 3 jam; sedangkan pada suhu nitridasi 400 dan $350{ }^{\circ} \mathrm{C}$ masing-masing masih terjadi peningkatan ketahanan aus sekitar 3,2 kali dan 2,6 kali terhadap cuplikan standar. Peningkatan ketahanan aus tersebut terutama akibat terbentuknya lapisan senyawa yang sangat keras pada permukaan cuplikan yang ternitridasi ion, seperti yang telah dijelaskan di atas.

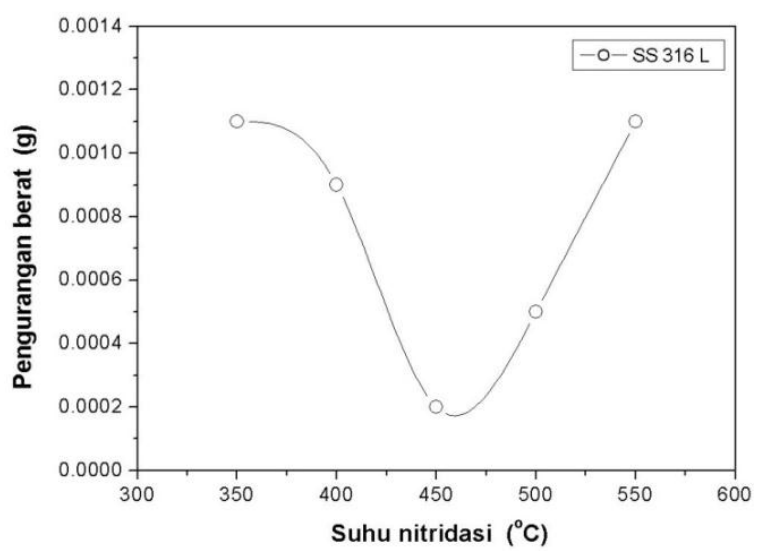

Gambar 3. Grafik ketahanan aus cuplikan SS 316L hasil nitridasi ion untuk variasi suhu nitridasi, pada tekanan gas nitrogen optimum 1,8 mbar dan waktu nitridasi optimum 3 jam. 
Untuk mengetahui struktur fase lapisan nitrida besi yang terbentuk pada permukaan cuplikan SS 316L dilakukan dengan menggunakan teknik XRD. Gambar 4 menampilkan pola difraksi cuplikan SS 316L setelah proses nitridasi ion pada suhu nitridasi 350,500 dan $550^{\circ} \mathrm{C}$. Berdasarkan informasi sudut hamburan, intensitas dan jarak antar bidang, setelah dicocokan dengan data JCPDS (Joint Comittee Powder on Diffraction Standards), pola difraksi cuplikan SS 316 L sesudah proses nitridasi menghasilkan puncak-puncak $\gamma_{N}(111), \mathrm{Cr}_{2} \mathrm{~N}(101), \gamma_{\mathrm{N}}(200)$, $\varepsilon-\mathrm{Fe}_{3} \mathrm{~N}(212), \mathrm{Cr}_{2} \mathrm{~N}(111), \gamma-\mathrm{Fe}_{4} \mathrm{~N}(300), \mathrm{CrN}(222)$ dan $\varepsilon-\mathrm{Fe}_{2} \mathrm{~N}(041)$; masing-masing dengan jarak antar-bidang $2,26671 \AA, 2,05039 \AA, 1,96968 \AA, 1,78103 \AA, 1,39812 \AA, 1,26402 \AA, 1,19391 \AA$ dan $1,16590 \AA$ pada sudut difraksi (20) $39,733^{\circ}, 44,133^{\circ}, 46,043^{\circ}, 51,253^{\circ}, 66,865^{\circ}, 75,093^{\circ}, 80,360^{\circ}$ dan $82,705^{\circ}$. Gambar 4(a) memperlihatkan bahwa pada suhu nitridasi rendah tidak hanya fase austenit terekspansi $\gamma_{\mathrm{N}}$ yang terbentuk, tetapi juga diperoleh nitrida besi $\varepsilon-\mathrm{Fe}_{2-3} \mathrm{~N}, \gamma^{\prime}-\mathrm{Fe}_{4} \mathrm{~N}$ dan nitrida krom $\mathrm{CrN}$ dan $\mathrm{Cr}_{2} \mathrm{~N}$. Pada Gambar 4(b) dan 4(c) untuk suhu nitridasi 500 dan $550{ }^{\circ} \mathrm{C}$, memperlihatkan bahwa intensitas fase austenit terekspansi $\gamma_{\mathrm{N}}$ menurun dan intensitas fase nitrida krom $\mathrm{CrN}$ dan $\mathrm{Cr}_{2} \mathrm{~N}$ meningkat; karena pada suhu nitridasi di atas $450{ }^{\circ} \mathrm{C}$ memberikan peningkatan mobilitas unsur krom sehingga memungkinkan terjadinya presipitasi nitrida krom dalam lapisan yang ternitridasi, dan mengakibatkan degradasi ketahanan korosi cuplikan SS 316L.

Fase austenit terekspansi $\gamma_{N}$ yang terbentuk pada nitridasi suhu rendah adalah fase metastabil paduan besi superjenuh dengan nitrogen dan dicirikan oleh pola difraksi sinar-X dengan puncak lebih lebar yang terdislokasi ke kiri relatif terhadap pola difraksi matriks austenitik standar dari stainless steel austenitik; hal ini disebabkan ekspansi konstante kisi yang disebabkan oleh penyisipan nitrogen ${ }^{(1,4,17)}$. Lapisan larutan padat interstisi ini memiliki sifat-sifat yang sangat keras atau mempunyai ketahanan keausan yang tinggi dan ketahanan korosi yang baik.

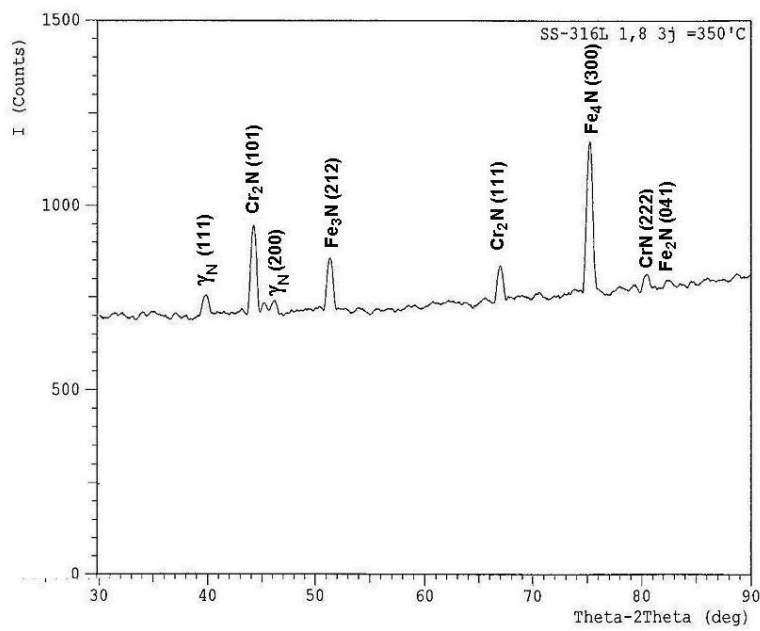

(a)

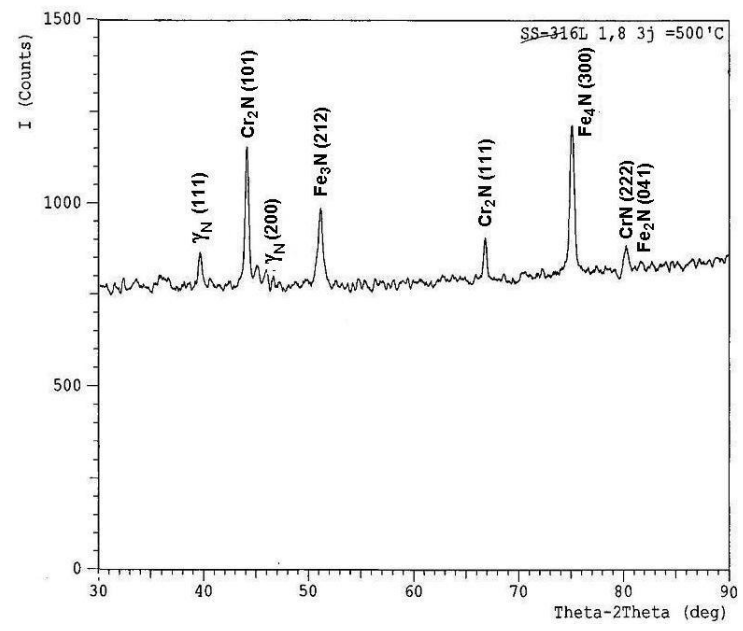

(b) 


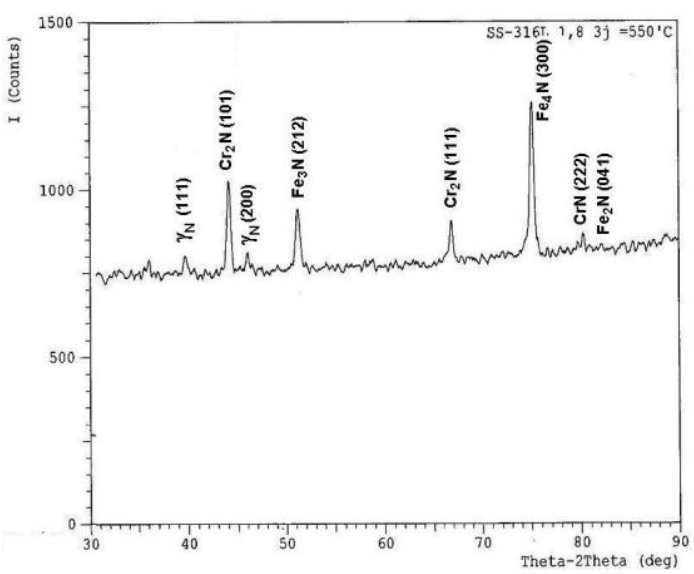

(c)

Gambar 4. Pola difraksi cuplikan SS $316 \mathrm{~L}$ hasil nitridasi ion untuk (a) suhu nitridasi $350^{\circ} \mathrm{C}$, (b) suhu nitridasi $500^{\circ} \mathrm{C}$ dan (c) suhu nitridasi $550^{\circ} \mathrm{C}$ pada tekanan gas nitrogen optimum 1,8 mbar dan waktu nitridasi optimum 3 jam.

Hasil serupa juga didapatkan oleh N. Mingolo dkk. ${ }^{(17)}$, dimana mereka melakukan nitridasi AISI 316L dalam campuran $75 \% \mathrm{~N}_{2} / 25 \% \mathrm{H}_{2}$ pada suhu nitridasi $400-550{ }^{\circ} \mathrm{C}$. Pada suhu nitridasi $400{ }^{\circ} \mathrm{C}$ selain diperoleh fase austenit terekspansi $\gamma_{\mathrm{N}}$ juga diperoleh nitrida besi $\varepsilon-\mathrm{Fe}_{3} \mathrm{~N}$ dan $\gamma^{\prime}-\mathrm{Fe}_{4} \mathrm{~N}$, serta nitrida $\mathrm{krom} \mathrm{Cr}_{2} \mathrm{~N}$; sedangkan selama nitridasi pada suhu $550{ }^{\circ} \mathrm{C}$ terjadi presipitasi nitrida secara intensif, meskipun fase $\gamma_{\mathrm{N}}$ juga terdeteksi. Selain itu, F.C. Nascimento dkk. ${ }^{(7)}$ juga memperoleh hasil yang serupa, nitridasi ion pada suhu $300{ }^{\circ} \mathrm{C}$ dihasilkan austenit terekspansi $\gamma_{\mathrm{N}}$ sebagai fase yang paling dominan, pada suhu nitridasi $400{ }^{\circ} \mathrm{C}$ selain dihasilkan fase $\gamma_{\mathrm{N}}$ juga diperoleh fase $\varepsilon-\mathrm{Fe}_{2+x} \mathrm{~N}, \gamma^{\prime}-\mathrm{Fe}_{4} \mathrm{~N}$ dan $\mathrm{CrN}$; sedangkan pada suhu nitridasi $500{ }^{\circ} \mathrm{C}$ hanya dihasilkan fase nitrida besi $\varepsilon-\mathrm{Fe}_{2+\mathrm{x}} \mathrm{N}, \gamma^{\prime}-\mathrm{Fe}_{4} \mathrm{~N}$ dan nitrida krom $\mathrm{CrN}$.

Seperti telah dibahas di atas, pada permukaan cuplikan SS 316L terbentuk fase $\gamma_{\mathrm{N}}$ yang mempunyai sifat istimewa, yaitu mempunyai kekerasan tinggi dan ketahanan korosi sangat baik; oleh karena itu pada penelitian ini juga dilakukan uji korosi untuk mengetahui ketahanan korosinya. Uji ketahanan korosi cuplikan SS 316L hasil nitridasi ion dilakukan dengan menggunakan larutan Hanks yang disimulasikan mirip dengan cairan tubuh manusia. Larutan Hanks dibuat dari bahan-bahan kimia yang terdiri dari: $\mathrm{NaCl} 8,0 \mathrm{~g} / \mathrm{l}, \mathrm{CaCl}_{2} 0,14 \mathrm{~g} / \mathrm{l}, \mathrm{KCl} 0,4 \mathrm{~g} / \mathrm{l}$, $\mathrm{NaHCO}_{3}$ 0,35 g/l, glukosa 1,0 g/l, $\mathrm{NaH}_{2} \mathrm{PO}_{4}$ 0,1 g/l, $\mathrm{MgCl}_{2} \cdot 6 \mathrm{H}_{2} \mathrm{O}$ 0,1 g/l, $\mathrm{Na}_{2} \mathrm{HPO}_{4} .2 \mathrm{H}_{2} \mathrm{O}$ 0,06 g/l, $\mathrm{MgSO}_{4} .7 \mathrm{H}_{2} \mathrm{O} 0,06$ $\mathrm{g} / \mathrm{l}$. Pengukuran laju korosi dilakukan menggunakan potensiostat PGS-201T, menghasilkan kurva potensial vs log intensitas rapat arus korosi. Berdasarkan kurva tersebut diperoleh data intensitas rapat arus korosi cuplikan SS $316 \mathrm{~L}$ untuk variasi suhu nitridasi $350-550{ }^{\circ} \mathrm{C}$. Besarnya laju korosi cuplikan terutama sebagai fungsi intensitas rapat arus korosi, dan juga berat ekivalen, kerapatan dan luas cuplikan. Oleh karena itu dengan menggunakan data-data intensitas rapat arus korosi untuk variasi suhu nitridasi $350-550{ }^{\circ} \mathrm{C}$ yang diperoleh dapat ditentukan laju korosi cuplikan SS 316L hasil nitridasi ion, seperti ditampilkan pada Gambar 5.

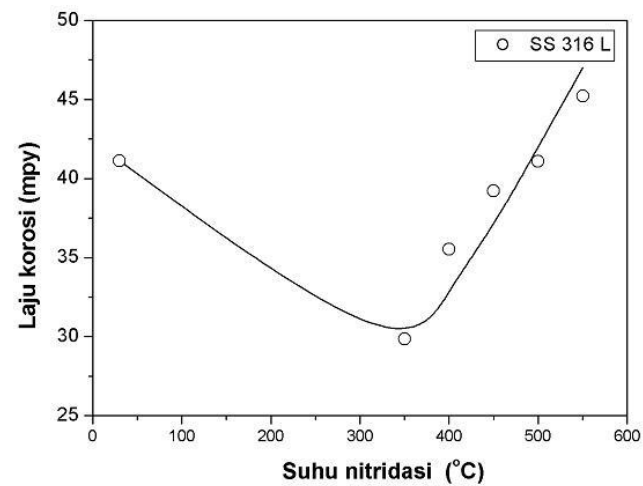

Gambar 5. Grafik laju korosi sebagai fungsi suhu nitridasi dari cuplikan SS 316L hasil nitridasi ion pada tekanan gas nitrogen optimum 1,8 mbar dan waktu nitridasi optimum 3 jam. 
Berdasarkan Gambar 5 tersebut diketahui bahwa laju korosi optimum cuplikan SS 316L sebesar 29,866 mpy pada suhu nitridasi $350^{\circ} \mathrm{C}$ atau meningkat $137 \%$, dan pada suhu tersebut juga terjadi peningkatan ketahanan aus 2,6 kali jika dibandingkan dengan cuplikan standar. Hal ini terjadi terutama karena pada permukaan cuplikan terbentuk fase austenit terekspansi $\gamma_{\mathrm{N}}$.

Pada suhu nitridasi yang lebih tinggi dari $350^{\circ} \mathrm{C}$ cenderung terjadi presipitasi atau pengendapan nitrida krom $\left(\mathrm{CrN}\right.$ dan $\mathrm{Cr}_{2} \mathrm{~N}$ ) yang hadir bersama struktur fase $\mathrm{Fe}_{3} \mathrm{~N}$ dan $\mathrm{Fe}_{4} \mathrm{~N}$. Terjadinya presipitasi nitrida krom tersebut selama proses nitridasi ion menyebabkan penurunan ketahanan korosi atau peningkatan laju korosi permukaan cuplikan SS 316L, hal ini akibat pengurangan kandungan krom bebas yang tersedia dalam matriks stainless steel untuk pembentukan lapisan permukaan protektif $(2,10,15)$. Pada suhu nitridasi rendah di bawah $450{ }^{\circ} \mathrm{C}$ akan memberikan mobilitas unsur krom cukup rendah untuk menghindari presipitasi nitrida krom pada lapisan permukaan cuplikan yang ternitridasi.

\section{KESIMPULAN}

Berdasarkan hasil dan pembahasan tersebut di atas dapat diambil kesimpulan sebagai berikut. Perlakuan permukaan cuplikan SS $316 \mathrm{~L}$ menggunakan teknik nitridasi ion yang dilakukan pada rentang suhu $350-550{ }^{\circ} \mathrm{C}$, tekanan gas nitrogen optimum 1,8 mbar dan waktu nitridasi optimum 3 jam dapat menghasilkan lapisan permukaan ternitridasi yang terdiri dari struktur fase austenit terekspansi $\gamma_{\mathrm{N}}$, nitrida besi dan nitrida krom. Pada suhu nitridasi rendah hingga $350{ }^{\circ} \mathrm{C}$ terbentuk struktur fase austenit terekspansi $\gamma_{N}$ dan fase $\gamma^{\prime}-\mathrm{Fe}_{4} \mathrm{~N}$ yang lebih dominan selain juga terbentuk fase $\varepsilon-\mathrm{Fe}_{3} \mathrm{~N}$ dan fase nitrida krom $\mathrm{CrN}$ dan $\mathrm{Cr}_{2} \mathrm{~N}$. Ketika suhu nitridasi dinaikkan hingga suhu $550{ }^{\circ} \mathrm{C}$, selain masih dihasilkan fase $\gamma_{\mathrm{N}}, \varepsilon-\mathrm{Fe}_{2} \mathrm{~N}$ dan $\mathrm{CrN}$ dengan jumlah atau intensitas yang kecil juga diperoleh fase $\gamma^{\prime}-\mathrm{Fe}_{4} \mathrm{~N}, \varepsilon-\mathrm{Fe}_{3} \mathrm{~N}$ dengan intensitas meningkat dan presipitasi $\mathrm{Cr}_{2} \mathrm{~N}$ dalam intensitas yang cukup besar. Fase austenit terekspansi $\gamma_{\mathrm{N}}$ atau fase nitrogen superjenuh ini memiliki sifat kekerasan atau ketahanan aus yang tinggi dan ketahanan korosi sangat baik. Berdasarkan uji keausan diperoleh peningkatan ketahanan aus sekitar 2,6 kali untuk suhu nitridasi ion $350{ }^{\circ} \mathrm{C}$; dan pada suhu nitridasi tersebut dari uji ketahanan korosi dalam larutan Hanks memperlihatkan bahwa ketahanan korosinya optimum, dan mengalami penurunan ketika suhu nitridasi dinaikkan; hal ini terjadi karena terbentuknya presipitasi nitrida krom pada lapisan permukaan yang ternitridasi.

\section{UCAPAN TERIMA KASIH}

Kegiatan penelitian ini sepenuhnya dibiayai dari Program Insentif Peningkatan Kemampuan Peneliti dan Perekayasa (PIPKPP) Tahun 2011, Kantor Kementerian Riset dan Teknologi. Oleh karena itu, pada kesempatan ini penulis mengucapkan terima kasih yang sebesar-besarnya kepada BATAN dan Kementerian Riset dan Teknologi yang telah menyetujui dan membiayai kegiatan penelitian yang kami lakukan, sehingga penelitian ini dapat dilaksanakan dengan baik.

\section{DAFTAR PUSTAKA}

1. F.A.P. FERNANDES, S.C. HECK, R.G. PEREIRA, A. LOMBARDI-NETO, G.E. TOTTEN and L.C. CASTELETTI, Journal Achievements in Materials and Manufacturing Engineering, Volume 40, Issue 2, (2010) 175-179

2. M. DROUET, J.C. STINVILLE, P. VILLECHAISE, J.P. RIVIERE, and C. TEMPLIER, Eur. Phys. Appl. Phys. 43, (2008) 349-351

3. A. NISHIMOTO, K. AKAMATSU, Plasma Processes and Polymers, 6 (2009) S306-S309

4. F. BORGIOLI, A. FOSSATI, E. GALVANETTO, T. BACCI, Surface \& Coatings Technology 200 (2005) 2474-2480

5. L. WANG, Y. LI, Y. WANG, Key Engineering Materials 373-374 (2008) 308-311

6. J. BARANOWSKA, Advances In Manufacturing Science and Technology, Vol. 32, No. 1, (2008) 59-68

7. F.C. NASCIMENTO, C.M. LEPIENSKI, C.E. FOERSTER, A. ASSMANN, S.L.R. DA SILVA, C.J. DE M. SIQUEIRA, A.L. CHINELATTO, J. Mater. Sci. 44 (2009) 1045-1053

8. K. SHETTY, S. KUMAR and P.R. RAO, Journal of Physics: Conference Series 100 (2008) 1-6 
9. SUDJATMOKO, WIRJOADI, B. SISWANTO, SUHARNI, T. SUJITNO, Jurnal Iptek Nuklir Ganendra, Volume 13, Nomor 2 (2010) 93-100

10. R.R.M. DE SOUSA, F.O. DE ARAUJO, J.A.P. DA COSTA, T. DUMELOW, R.S. DE OLIVEIRA, C. ALVES, Jr., Vacuum 83 (2009) 1402-1405

11. S. H. AHN and I. LEE, J. Mater. Sci. Technol., Vol. 24, No. 3, (2008) 356-358

12. E.A. OCHOA, C.A. FIGUEROA, and F. ALVAREZ, Surface and Coating Technology, Volume 200, Issue 7 , (2005) 2165-2169

13. S.R. HOSSEINI and F. ASHRAFIZADEH, International Journal of ISSI, Vol. 5, No. 2, (2008) 29-35

14. J.C. DIAZ-GUILLEN, A. CAMPA-CASTILLA, S.I. PEREZ-AGUILAR, E.E. GRANDA-GUTIERREZ, A. GARZA-GOMEZ, J. CANDELAS-RAMIREZ, R. MENDEZ-MENDEZ, Effect of duty cycle on surface properties of AISI 4340 using a pulsed plasma nitriding process, Superficies y Vacio, 22(1) (2009) 1-4

15. Y.T. XI, D.X. LIU, D. HAN and Z.F. HAN, Acta Metall. Sin. (Engl.Lett.), Vol. 21, No. 1 (2008) 21-29

16. S.Y.SIRIN, K. SIRIN, E. KALUC, Materials Characterization 59 (2008) 351-358

17. N. MINGOLO, A.P. TSCHIPTSCHIN, C.E. PINEDO, Surface \& Coatings Technology 201 (2006) 4215-4218 